\title{
Medical Waste Management is Vital for Safe Town Development: An Incident Study in Jessore Town, Bangladesh
}

\author{
Uday Som ${ }^{1}$, Md. Shameem Hossain ${ }^{2 *}$ \\ 1 Jessore University of Science \& Technology, Department of Chemical Engineering, Jessore-7408, BANGLADESH \\ 2 Khulna University of Engineering \& Technology, Department of Energy Science and Engineering, Khulna-9203, \\ BANGLADESH
}

*Corresponding Author: shameemkuet@gmail.com

Citation: Som, U. and Hossain, M. S. (2018). Medical Waste Management is Vital for Safe Town Development: An Incident Study in Jessore Town, Bangladesh. European Journal of Sustainable Development Research, 2(3), 36. https://doi.org/10.20897/ejosdr/2668

Published: July 17, 2018

\begin{abstract}
Health care institutions (HCIs) generate waste which can causes various injuries and infections to the patients, healthcare workers and also causes harm to the surrounding environment. Medical waste management (MWM) is vital for safe town development and the misconduct of medical waste may be a significant risk factor for the infectious diseases diffusion on our environment. The study carried out on 22 HCIs included public hospital, diagnostic centers, private hospitals and clinic in Jessore town of Bangladesh. This present study focused on the existing management structure, generation rate and difficulties of MWM. An inadequate number of HCIs are following the MWM method over their self-management. The findings of this study exposed that around 3 ton of medical waste is produced per day that is about $5.56 \%$ of entire waste production in this town. Over on an ordinary $0.98 \mathrm{~kg} /$ day $/$ bed medical waste that covering $10.89 \%$ infectious, $15.82 \%$ plastic, $3.46 \%$ sharp, $3.87 \%$ pathological, $60.94 \%$ domestic and $5.52 \%$ pharmaceutical waste were generated in this town.
\end{abstract}

Keywords: medical waste (MW), health care institutions (HCIs), health effect, handling of medical waste, medical waste management (MWM)

\section{INTRODUCTION}

Bangladesh is a developing country with a swiftly developing urban population, widespread health problems, little educational status and great environmental pollution (Kabir et al., 2003; Rahman et al., 2007). Medical waste is a subject of mounting concern since difficult of medical waste is appeared as one of the most significant phenomena over the past three decades (Halder et al., 2014). One estimation shows that several 5.2 million people (comprising 4 million children) die each year in the sphere from waste-related diseases (World Bank, 2002). So as to safeguard a sound environment for our health, MWM is a compulsory phenomenon. Medical wastes usually account for a very minor fraction, about one percent of the entire solid wastes produced in Bangladesh (World Bank, 2002) that can be extremely toxic as well as infective and unrestrained damping of this waste threatens environmental and human health. Healthcare waste management (HCWM) is stagnant a foremost challenge for health services in developing countries where the health care staff and nearby population is unprotected to risks because of deprived handling of waste (Lee et al., 2002). Medical waste is accomplished of causing sicknesses and illness to publics, either through direct or indirectly by polluting ground water, surface water, soil and air (Abdulla et al., 2008). Up till now, there was no well-organized scheme for appropriate medical waste management (MWM) in Bangladesh to protect environmental health dangers. A decent number of international and national studies 
Table 1. Classification of medical waste

\begin{tabular}{llll}
\hline $\begin{array}{l}\text { Laboratory waste } \\
\begin{array}{l}\text { Chemicals used in the } \\
\text { pathological lab }\end{array}\end{array}$ & Clinical waste & Non-clinical waste & Kitchen waste \\
\hline $\begin{array}{l}\text { Microbial cultures and clinical } \\
\text { specimens }\end{array}$ & Gauze and bandages & $\begin{array}{l}\text { Plastics that have no contact with } \\
\text { body fluid }\end{array}$ & $\begin{array}{l}\text { Potential source of vermin and } \\
\text { pest }\end{array}$ \\
\hline Needle & Vials & Ofapping paper & Food waste \\
\hline Culture dish & Body fluids & & \\
\hline Syringes & Glassware & & \\
\hline Radioactive waste & Drainage bags & \\
\hline Slide & Culture dishes & & \\
\hline
\end{tabular}

described that there have been very partial good practices of disposal or dumping of health care waste in Bangladesh. It has been informed that maximum of the hospitals, excluding a few private hospitals, dispose health care wastes beside the road sides as the commercial and solid wastes are disposed (World Bank, 2002; Uddin, 2007). Improper dumping of medical waste may comprise damage to humans by harsh instruments, diseases transferred to humans by infective agents, and pollution of the environment by hazardous and toxic chemicals (Jang et al., 2006; Ross, 2011). The mishandling of the biomedical waste poses serious risk to publics and the environment. It is significant to dispose of such waste correctly to avoid its hazardous effects (Saini et al., 2004). The effects of mishandled hospital waste are said to be massive and extreme. It is necessary to increase awareness of biomedical waste management among public and health care workers and it is the duty of the health care providers and health care facility to safety measure the health of workers those who are involved in transportation, disposal and handling, of biomedical waste (Ananthachari and Divya, 2016). When open burning of bio-medical waste occur it is the most injurious practice and if it inhaled can be cause respiratory diseases (Hussain et al., 2018). The medical waste management method comprises handling, segregation, disinfection, storage, collection, transportation and final disposal. Poor management, deficiency of handling information and unempirical disposal of numerous health-care wastes produce serious direct and indirect community health intimidations to health-care nurses, technicians, personnel, waste workers, patients, hospital visitors, surrounding communities and the environment as well (Biswas et al., 2011). In the case of Bangladesh utmost of the waste handlers are from lower socio-economic situation with big family size, lower level of learning and knowledge. They typically handle the medical wastes without using necessary equipment (Uddin, 2007). Therefore; MWM is the key portrait for innocuous town development for a developing country like Bangladesh. The key goal of this study is to emphasis on the managing scenarios and conceivable threats of hospital waste in Jessore town. Also this study is endeavored to focus on the demand of MWM for protecting and safeguarding health of environment.

\section{Medical Waste}

There is no on its own definition of "medical waste". The terms medical wastes, hospital wastes and infectious wastes have continually been castoff interchangeably (Lee et al., 2002). Medical wastes are infective and hazardous. Medical waste can be reasons serious threats to environmental health and needs precise management and handling previously to its concluding disposal (Hassan et al., 2008). Medical wastes are arising from analysis monitoring and preventive, relaxing or therapeutic activities in the pulverized of the veterinary and human medicine (BAN and HCWN, 1999). The new progresses medical services are exactly made for the anticipation and safety of the public health. In numerous processes for diseases treatment the exhausting of sophisticated instruments is rising. Such advances and development in scientific knowledge has initiated in per capita per patient generation of wastes in healthcare entities (Radha et al., 2009). The classification of medical waste is as shown in Table 1.

\section{METHODOLOGY}

\section{Study Area}

Jessore, is the present study area, the main district of undivided Bengal which is an increasing center of southwestern Bangladesh. It is a major industrialized and commercial center stands on the bank of the river Bhairob. Jessore district is presently covers region of $2578.20 \mathrm{sq}$. $\mathrm{km}$ in which Jessore town covers a region of $25.72 \mathrm{sq} . \mathrm{km}$. and the residents of the district was around 2,440,693 in 2012 estimation. In fact Jessore town has a population $(1,178,273)$ nearly half of that of the entire district (Bangladesh Bureau of Statistics, 2012). The district lies between $22^{\circ} 48^{\prime}$ and $23^{\circ} 22^{\prime}$ north latitudes and between $88^{\circ} 51^{\prime}$ and $89^{\circ} 34^{\prime}$ east longitudes. Jessore town appearances an excessive environmental difficulty due to inappropriate management of MSW. Entirely the waste of Jessore town is dumped in two particular areas of Hamidpur and Jhumjhumpur. This study has been planned to selection of healthcare institutes, collection of primary and secondary data, field observation data analysis and lastly proposals for the development of present situation of MWM as shown in Figure 1. 


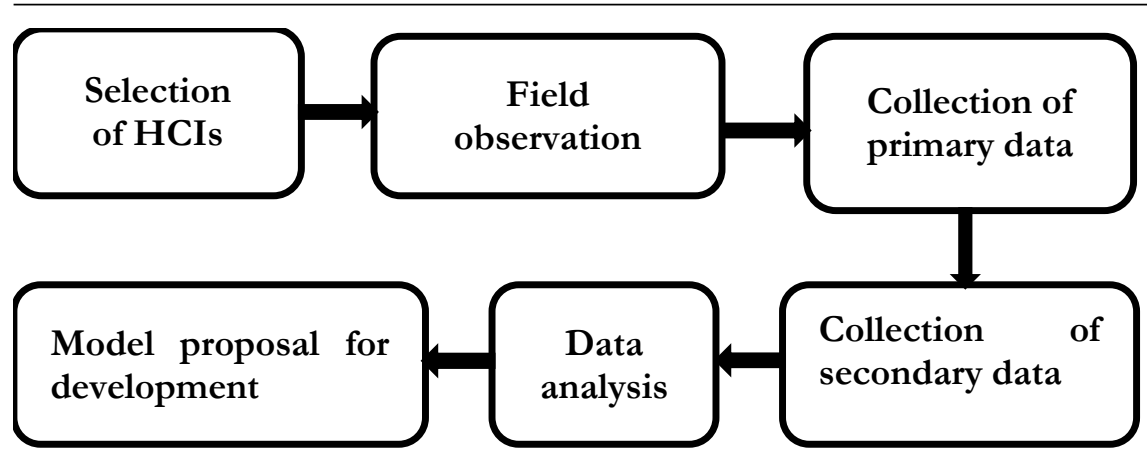

Figure 1. Planning of study

Table 2. Name of the selected HCEs

Name of the selected health care establishment

Queens Hospital (pvt.) Ltd.

Lab Aid Hospital and Diagnostic Centre

250 beded General hospital, Jessore

Ekota Hospital and Diagnostic Complex (Pvt) Ltd.

Doratana Hospital

Unique Hospital and Diagnostic Centre

Modern Hospital and Diagnostic Centre

Ad-din Shisu Hospital

Ad-din Shakhina medical college Hospital (Ad-dinmadical)

Rotary Health care center

Central Hospital and Diagnostic complex

Ibn-Sina Hospital and Diagnostic Centre

Jonokollan Hospital

Squaire Diagnostic Centre

Lab scan diagnostic center

Sunrise Diagnostic Centre

Popular Diagnostic Centre

Prime Diagnostic Centre

Comtech Diagnostic Centre

Nova medical Center

Jhorna Clinic

Jonota Hospital and diagnostic center

\section{Samples and Procedure}

No statistically rigorous sampling process could be followed for this study. That Health Care Establishment (HCE) who was willing to afford us info was selected for this study. It was not informal to collect appropriate medical waste data from HCE ever since utmost of the HCE did not keep an eye on the prevailing regulation and rules to run them appropriately. For this cause some of the HCE the ruling classes were not attentive to give consent in gathering data from their own establishments. A total of 22 out of existing 69 HCE in the study area gave consent to gather data. Primary data were collected through Interview, actual measurement, direct field observation and questionnaire survey. A face-to-face direct key informant interview was completed among the diverse respondent group. Previously entering a HCE, a numeral of official meetings being organized with the apprehensive authority of each HCE to elucidate the effectiveness of the study and pursue their cooperation. Afterward receiving consent, investigation was started. Sampled establishment were nominated using random sampling technique intended for data collection. Equally primary and secondary data have been collected for this study. Name of the selected health care establishments are as shown in Table 2.

A practical questionnaire survey was passed out for the gathering of primary data about the remaining management scheme of medical waste in the study area finding factors which frontier suitable disposal of medical waste in Jessore City. The respondents comprised, pathology technician, authority staffs, nurses, room service employees and cleaner. Data were collected from 300 respondents among them 25 authority staffs, 120 nurses, 48 room service employees, 47 cleaners, 24 pathology technicians and 36 ward boys. 
Table 3. Distribution of waste generation

\begin{tabular}{lccc}
\hline Waste type & $\begin{array}{c}\text { Maximum value } \\
\text { (kg/day/bed) }\end{array}$ & $\begin{array}{c}\text { Minimum value } \\
\text { (kg/day/bed) }\end{array}$ & $\begin{array}{c}\text { Mean } \\
\text { (kg/day/bed) }\end{array}$ \\
\hline Total waste & 1.390 & 0.570 & 0.980 \\
\hline Plastic waste & 0.141 & 0.047 & 0.188 \\
\hline Sharp waste & 0.013 & 0.004 & 0.017 \\
\hline Infectious waste & 0.075 & 0.025 & 0.100 \\
\hline Pharmaceutical waste & 0.039 & 0.005 & 0.044 \\
\hline Pathological waste & 0.026 & 0.008 & 0.034 \\
\hline Domestic waste & 0.448 & 0.149 & 0.597 \\
\hline
\end{tabular}

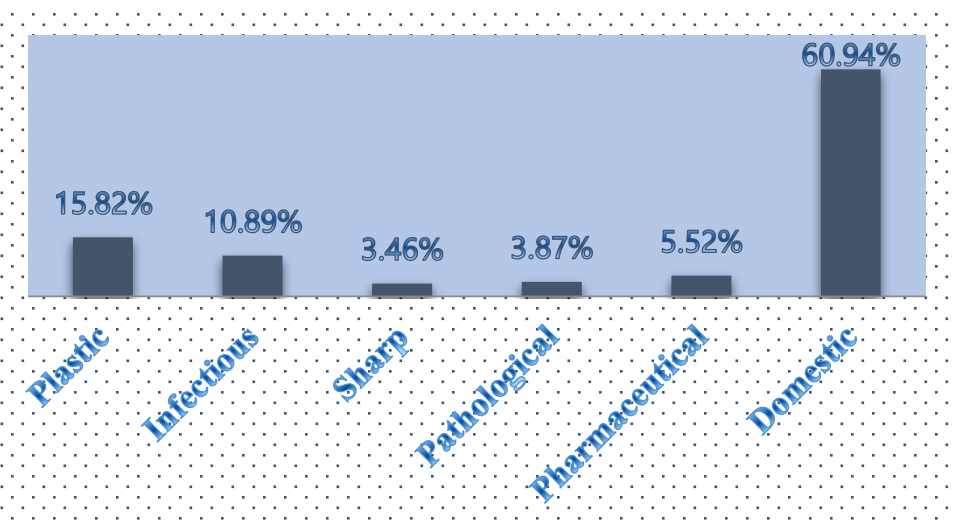

Figure 2. Types of medical waste $(\%)$

Table 4. Waste generation rate per patient

\begin{tabular}{lccccc}
\hline HCEs & No of beds & $\begin{array}{c}\text { No. of in } \\
\text { patients }\end{array}$ & $\begin{array}{c}\text { No. of Out } \\
\text { patients }\end{array}$ & $\begin{array}{c}\text { Total generated } \\
\text { waste (kg) }\end{array}$ & $\begin{array}{c}\text { Waste generation rate } \\
\text { (Kg patient }^{-1} \text { day }^{-1} \text { ) }\end{array}$ \\
\hline Public Hospital (1) & 300 & 400 & 800 & 610 & 0.51 \\
\hline $\begin{array}{l}\text { Private Hospital/ Clinic and Diagnostic } \\
\text { (16) }\end{array}$ & 650 & 370 & 1090 & 810 & 0.55 \\
\hline Pathology/Diagnostic (5) & 0 & 0 & 250 & 90 & 0.36 \\
\hline
\end{tabular}

\section{RESULT AND DISCUSSON}

\section{Waste Generation}

Medical waste produced from the regular events of the nurses, cleaners, sweepers, patients, doctors and administrators etc. that are rejected as useless. Medical wastes are formed from the cabin, Operation theatre, outpatient department, ward, pathology etc. Size of the waste mainly rest on upon the outdoor patients and beds that signify the sources of waste generation. The average waste production rate is $0.980 \mathrm{~kg} / \mathrm{day} / \mathrm{bed}$ where the infectious waste production rate is $0.100 \mathrm{~kg} / \mathrm{day} / \mathrm{bed}$. Distribution of waste generation is as shown in Table 3 .

Furthermore, from this study the quantity of clinical waste (except domestic waste) was established to be 0.79 ton/day. In mixture, around 54 ton solid waste is generated in this town that comprises 3 ton of medical waste (both domestic waste and clinical) that is around $5.56 \%$ of total solid waste production. Types of medical waste $(\%)$ are as shown in Figure 2.

In this present study it was initiate that the waste production rate (kg patient-1 $\left.\mathrm{day}^{-1}\right)$ in the public hospital is lower than private clinic but higher than the other diagnostic center. The generation rate $\left(\mathrm{kg}\right.$ patient- $\left.{ }^{1} \mathrm{day}^{-1}\right)$ in the public hospital, private clinic and diagnostic center were $0.51,0.55$ and $0.36 \mathrm{~kg}$ patient ${ }^{1} \mathrm{day}^{-1}$ that are showed in Table 4. The waste production rate in the private clinic was highest because of large number of the outdoor patient was come in there to get the immediate and better technological services (Rahman et al., 2013).

\section{Handling of Medical Waste}

The prevailing Environment Conservation Rules, 1997 had no detailed laws directly related to MWM. Usually, the rule comprises proposal for use of diverse color coded container (CCCs) for isolation of medical waste at source and symbol to be castoff on the packing of medical waste and transference. The rule identifies the standard for Pyrolysis, deep burial, Incineration, and radioactive waste disposal and treatment. Pyrolysis is the appropriate method of hazardous waste dumping and regaining of energy from it (Hossain et al., 2017). In this study investigated that only around 28\% HCEs use CCCs for the separation of numerous kinds of wastes while about 


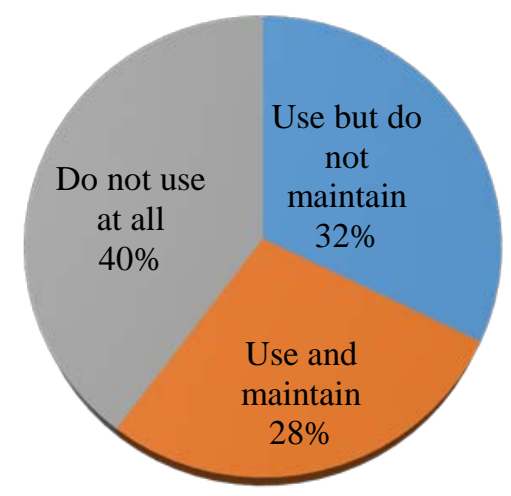

Figure 3. Uses of color coded container (\%)

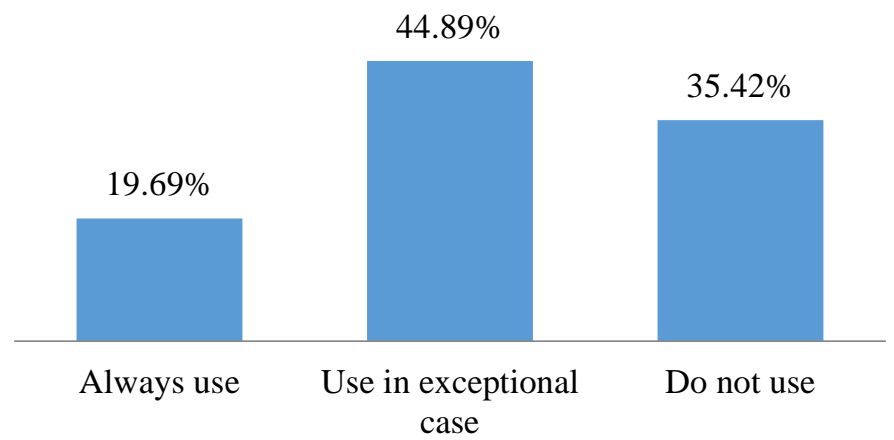

Figure 4. Uses of proactive wear (\%)

Table 5. Waste separation position

\begin{tabular}{lccc}
\hline Position of waste segregation by HCEs & Sharp & Infectious & Plastic \\
\hline At the time of generation & $26.97 \%$ & $14.46 \%$ & $29 \%$ \\
\hline In wards & $24.70 \%$ & $7.82 \%$ & $31.79 \%$ \\
\hline Collection time & & $25.43 \%$ & \\
\hline Do not segregate & $48.33 \%$ & $52.29 \%$ & $39.21 \%$ \\
\hline
\end{tabular}

$32 . \%$ hospitals do not use it properly regardless of having CCCs as suggested by ECR'97 and WHO. However, approximately $40 \%$ HCEs do not have any CCCs whatever. The present situation of use color coded container $(\%)$ is as shown in Figure 3.

Furthermore, very nearly all the HCEs do not follow any inscribed guidelines and naturally the cleaners do not have any alertness regarding the significances of medical waste (Rahman et al., 2013). The systematic use of proactive wear as suggested by PRISM Bangladesh and ECR'97 was found to be only $19.69 \%$ while for exceptional cases it was $44.89 \%$ and in $35.42 \%$ cases they do not use it whatever. The present situation of use proactive wear $(\%)$ is as shown in Figure 4.

\section{Waste Separation Position}

It was initiate that about $24.70 \%$ HCEs separated sharp equipment in the wards, 26.97\% HCEs were complete it at the time of generation and about $48.33 \%$ HCEs did not segregated it at all. Moreover, around 14.46\% HCEs separated infectious waste at the time of generation, while $25.43 \%$ HCEs separated infectious waste at the time of collection and $52.29 \%$ HCEs did not completed separation operation of infectious at all. The separation situations of various types of waste are as shown in Table 5.

\section{Storage, Collection and Transportation}

In all studied HCEs, utmost of the types of wastes were kept in CCC or the provisional storage or dustbin outer side of the hospital premises deprived of any disinfection. It was also initiated that some medical staffs earn some money through selling secondhand syringes and additional medical wastes. Over some wastes are dumped into the nearest river of Daratana which contaminates the river water constantly. Now and then waste were found to be discarded in the hospital premises for an extended period of time deprived of any management or any kind of disinfection process. The present scenario of medical waste damping is as shown in Figure 5. 


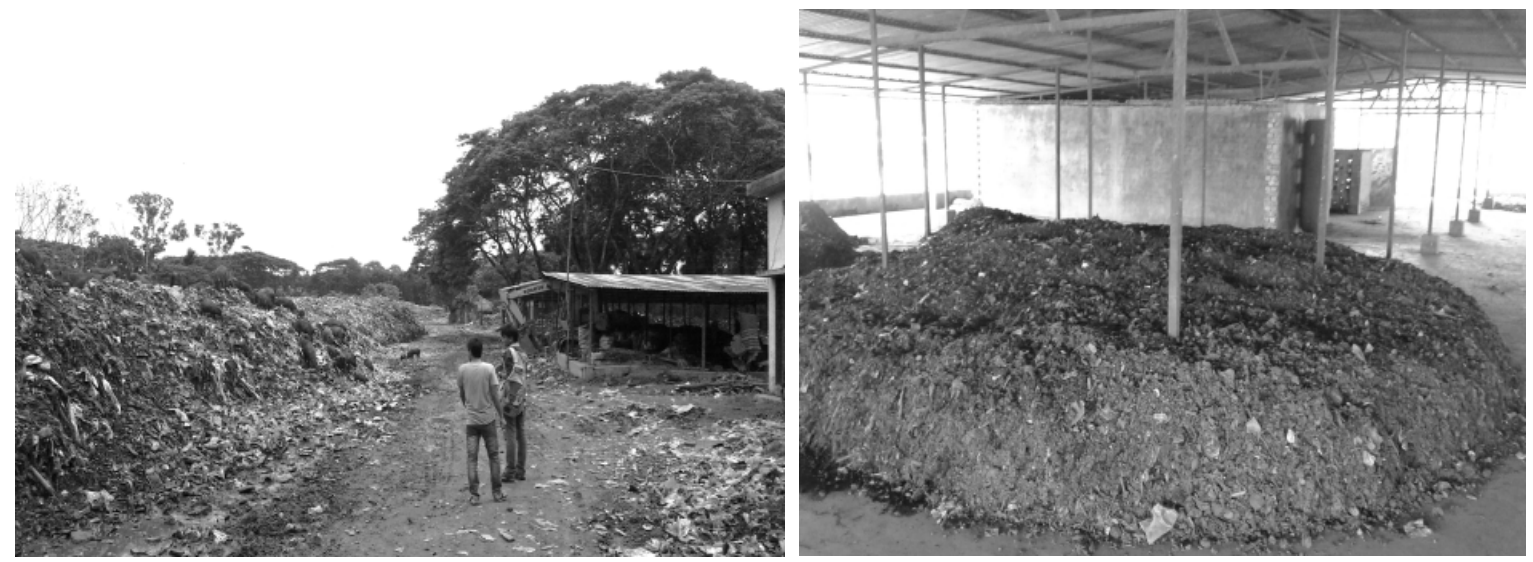

Figure 5. Present scenario of waste disposal in jessore (Mondol et al., 2016)

Table 6. Compare between the present study and (Rahman et al., 2013) about problems of handling MW identified by the respondents

\begin{tabular}{lcc}
\hline Problems for proper waste management system & Present study (\%), $\mathbf{N}=\mathbf{3 0 0}$ & Rahman et al. 2013 (\%), N=263 \\
\hline Absences of adequate dustbin & 12.52 & 14.91 \\
\hline Lack of awareness & 11.39 & 13.29 \\
\hline Lack of knowledge of the manpower & 10.64 & 12.54 \\
\hline Lack of trained and sufficient manpower & 09.28 & 11.29 \\
\hline Lack of proper segregation & 09.52 & 10.54 \\
\hline Mishandling of medical waste & 8.99 & 8.92 \\
\hline Lack of appropriate guideline & 6.62 & 4.62 \\
\hline Due to offensive odor & 5.68 & 4.62 \\
\hline Reuse or resell of waste materials & 5.24 & 3.24 \\
\hline No enforcement of law & 3.98 & 3.06 \\
\hline Lack of government budget in this sector & 5.09 & 3.18 \\
\hline Lack of monitoring of the HCEs & 2.99 & 2.87 \\
\hline Possibility of Disease infection & 3.91 & 1.93 \\
\hline No chain of command & 2.15 & 1.93 \\
\hline Negligence of the authority & 1.00 & 1.56 \\
\hline Insufficient technology for waste treatment and disposal & 1.00 & 1.50 \\
\hline
\end{tabular}

\section{Present Waste management problems Identified by the Respondent}

There were numerous kinds of difficulties identified by the respondents for the Jessore city to handling the appropriate waste management. Outcomes of the respondent view compared with (Rahman et al., 2013) about difficulties of waste handling identified by the respondents are as shown in Table 6 .

It is clear that there was a deficiency of adequate number of basket for the collection and storage of waste. Highest number of respondents talks about the lack of adequate bin, lack of awareness, lack of knowledge of the manpower for handling, lack of sufficient and trained manpower etc.

\section{Health Effect}

Waste managers are distressed by diverse types of the health effect because of pathogenic organisms of medical waste. One assessment shows that a number of such that 5.2 million people (comprising 4 million children) die each year in the sphere from waste-related diseases (World Bank, 2002). By survey it was detected those respondents were suffering from vomiting and headache in higher percentage $35 \%$ and $32 \%$ respectively. Some of the respondents met heart pain $(18 \%)$ for the period of the waste handling particularly the anatomical waste during the first time of the services. The present scenarios of diseases, people who are related to waste handling of medical waste purpose are as shown in Figure 6.

\section{SUGGESTED MODEL FOR MWM}

Throughout the survey the respondents opined for the development of the present medical waste management system. They suggested for the HCEs authority for providing adequate amount of dustbin and regular monitoring for the wellbeing of the management of the medical waste. Respondents moreover provided their opinion for the government actions which should be taken for the development of medical waste management system and safe the environment. They also recommended for the government sector for the systematic valuation of the 


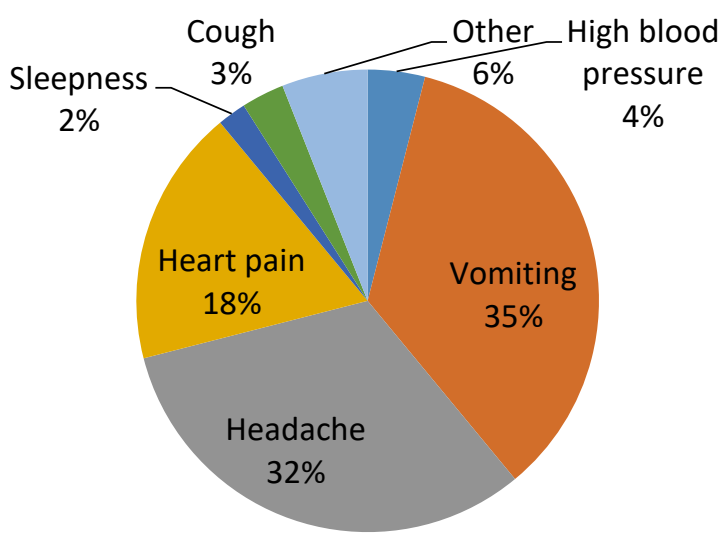

Figure 6. Health effect associated with MW handling

Table 7. Proposal for upgrading of existing waste management system in the Jessore city

\begin{tabular}{ll}
\hline 1 & Afford sufficient quantity of waste bin \\
\hline 2 & Adequate amount of colored coded waste bin \\
\hline 3 & Suitable technical instrument for waste handling and disposal \\
\hline 4 & Establishment of an environmentally sound medical waste treatment and disposal scheme \\
\hline 5 & Encourage people for recovery of resource from medical waste \\
\hline 6 & Confirming worker safety through training, education and appropriate personal protective equipment. \\
\hline 7 & Afford suitable place for waste disposal \\
\hline 8 & Construct law and enforce it \\
\hline 9 & Provide satisfactory budget for waste management sector \\
\hline 10 & Disinfection of the wastes before disposal. \\
\hline 11 & Establishment of a separate unit for sharp \\
\hline 12 & Provide suitable guideline to the worker \\
\hline 13 & Conduct with diverse NGOs for the development of the existing waste management \\
\hline 14 & Systematic monitoring \\
\hline 15 & Construct waste safety department \\
\hline
\end{tabular}

Source: Field survey, 2017

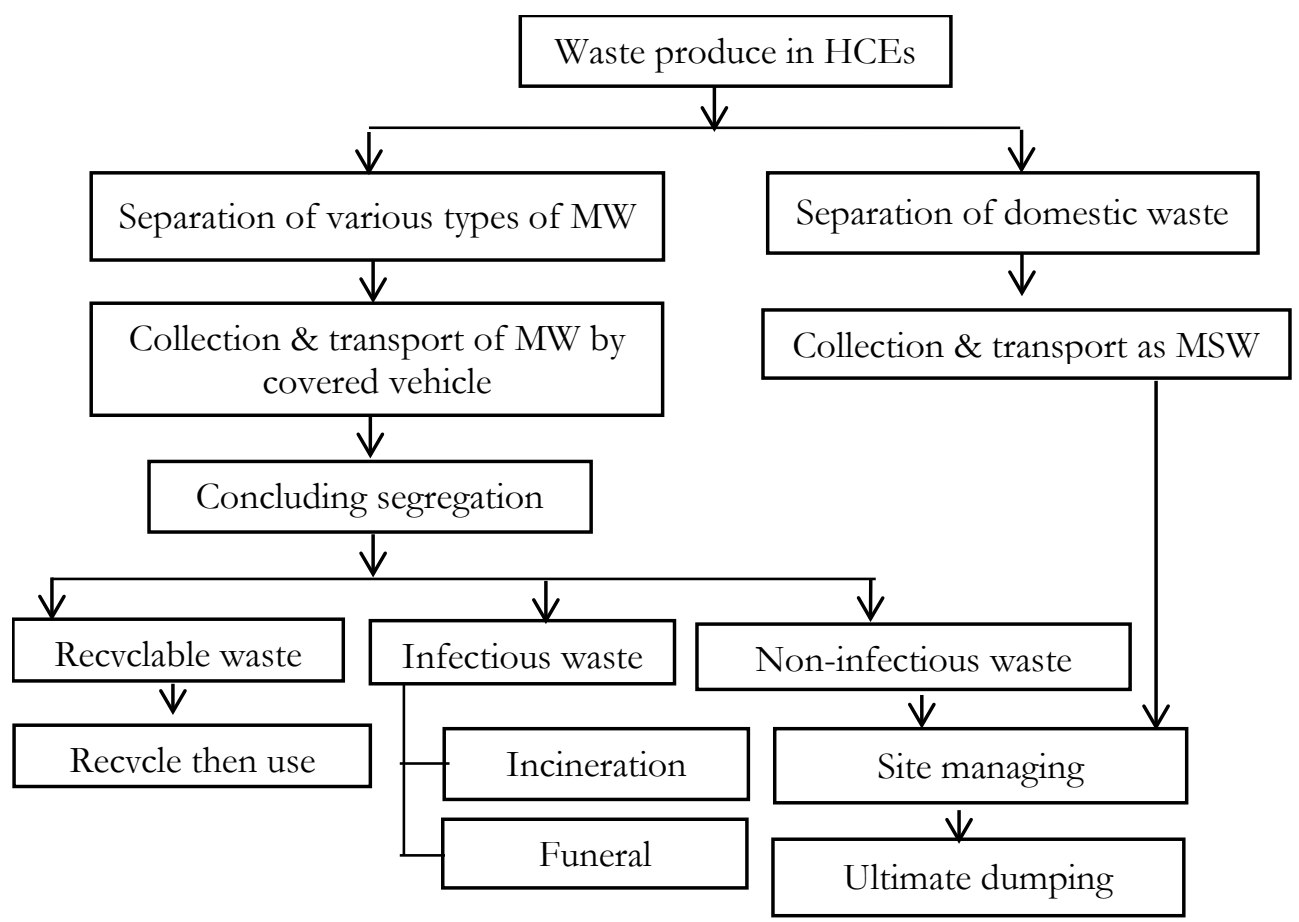

Figure 7. Model for MWM

monitoring by the specialist and arrangement of the program for increasing awareness. Respondent recommended various tricks for safe management. Proposal for upgrading of existing waste management system in the Jessore city are as shown in Table 7. 


\section{CONCLUSION}

It is incredible to replicate a safe town without proper management of waste especially medical waste. This study has been concentrated on the management situations and possible threats of medical waste in Jessore city of Bangladesh. The findings of this study expose that around 3 ton of medical waste is produced each day. Separations of numerous types of waste are not set up to be done satisfactorily in most of the health care establishments (HCEs). Additionally, there was no indication of accomplishment of disinfection operation for maximum of medical waste and the provision of color coded container (CCC) was not retained appropriately. MWM must be measured as a major issue in the modern age. This study has been appraised the key structures of the current situation of MWM in Jessore city and the impending strategy for proceeding this state.

\section{NOMENCLATURE}

$\begin{array}{ll}\text { Symbol } & \text { Meaning } \\ \text { MW } & \text { Medical Waste } \\ \text { MSW } & \text { Municipal Solid Waste } \\ \text { MWM } & \text { Medical Waste Management } \\ \text { HCEs } & \text { Health Care Establishments } \\ \text { HCIs } & \text { Health Care Institutions }\end{array}$

\section{REFERENCES}

Abdulla, F., Qdais, H. A. and Rabi, A. (2008). Site investigation on medical waste management practices in northern Jordan. Waste management, 28(2), 450-458. https://doi.org/10.1016/j.wasman.2007.02.035

Ananthachari, K. R. and Divya, C. V. (2016). A study on assessment of knowledge on biomedical waste management among health care workers of Malabar Medical College Teaching Hospital, Calicut, Kerala, India. International Journal of Community Medicine and Public Health, 3(9), 2409-2413.

Biswas, A., Amanullah, A. S. M. and Santra, S. C. (2011). Medical waste management in the tertiary hospitals of Bangladesh: an empirical enquiry. AS A University Review, 5(2), 149-158.

BAN and HCWH. (1999). An Analysis with a Case study of India and A critique of the Basel-TWG Guidelines, Basel Action Network (BAN) Secretariat Asian-Pacific Environmental Exchange, Medical Waste in Developing Countries.

Hussain, A., Gupta, S. and Koli, S. K. (2018). Biomedical Waste Management India: A Review.

Hassan, M. M., Ahmed, S. A., Rahman, K. A. and Biswas, T. K. (2008). Pattern of medical waste management: existing scenario in Dhaka City, Bangladesh. BMC Public Health, 8(1), 36. https://doi.org/10.1186/1471-24588-36

Halder, P. K., Paul, N., Hoque, M. E., Hoque, A. M., Parvez, M. S., Rahman, M. H. and Ali, M. (2014). Municipal solid waste and its management in Rajshahi City, Bangladesh: a source of energy. International Journal of Renewable Energy Research (IJRER), 4(1), 168-175.

Hossain, M. S., Som U, Hossain j., Wasikur Rahman, M. and Iqbal, S. A. (2017). Recovery of Alternative Fuel from Thermal Pyrolysis of Medical Wastes. In Proceedings of the 4th the International Conference on Engineering Research, Innovation and Education (ICERIE 2017), 13-15 January, SUST, Sylhet, Bangladesh, pp. 683-688.

Jang, Y. C., Lee, C., Yoon, O. S. and Kim, H. (2006). Medical waste management in Korea. Journal of environmental management, 80(2), 107-115. https://doi.org/10.1016/j.jenvman.2005.08.018

Kabir, Z. N., Tishelman, C., Agüero-Torres, H., Chowdhury, A. M. R., Winblad, B. and Höjer, B. (2003). Gender and rural-urban differences in reported health status by older people in Bangladesh. Archives of Gerontology and Geriatrics, 37(1), 77-91. https:// doi.org/10.1016/S0167-4943(03)00019-0

Lee, B. K., Ellenbecker, M. J. and Moure-Eraso, R. (2002). Analyses of the recycling potential of medical plastic wastes. Waste management, 22(5), 461-470. https://doi.org/10.1016/S0956-053X(02)00006-5

Rahman, M. S., Moumita, C. and Rikta, K. (2013). Medical Waste Management System: An Alarming Threat (A Case Study on Jessore Municipality, Bangladesh). Journal of Environmental Science and Natural Resources, 6(2), 181189.

Mondol, U., Hossain, M. S. and Saha, R. (2016). Recovery of Electric Energy from Municipal Solid Waste of Jessore Town in Bangladesh.

Population and Housing Census. (2011). Bangladesh Bureau of Statistics (2012). Available at: http://203.112.218.66/WebTestApplication/userfiles/Image/Census2011/Khulna/Jessore/Jessore\%20at\%2 0a\%20glance.pdf (Accessed 7 June 2017) 
Radha, K. V., Kalaivani, K. and Lavanya, R. (2009). A case study of biomedical waste management in hospitals. Global journal of health science, 1(1), 82-88.

Rahman, M. A., Islam, M. T. and Baten, M. A. (2007). Waste disposal and management system in rural and municipal areas of Dinajpur district. Bangladesh J. Environ. Sci, 13(1), 35-38.

Ross, D. E. (2011). Safeguarding public health, the core reason for solid waste management.

Saini, S., Das, B. K., Kapil, A., Nagarajan, S. S. and Sarma, R. K. (2004). The study of bacterial flora of different types in hospital waste: evaluation of waste treatment at Aims Hospital, New Delhi.

World Bank. (2002). Health Facility Waste Management Study in Dhaka, Bangladesh.

WHO (World Health Organization). (1999). Safe Management of Wastes from Health-Care Activities. Geneva. 